\title{
Asymmetric Rh-Catalyzed Intermolecular Hydroacylation of 1,5-Hexadiene with Salicylaldehyde
}

\author{
Yasuhiro InUI, ${ }^{a}$ Masakazu TANAKA $,{ }^{*}, a, b$ Masanori ImaI ${ }^{c}$ Keitaro TANAKA, ${ }^{a}$ and Hiroshi Suemune* ${ }^{*} a$ \\ ${ }^{a}$ Graduate School of Pharmaceutical Sciences, Kyushu University; 3-1-1 Maidashi, Higashi-ku, Fukuoka 812-8582, \\ Japan: ${ }^{b}$ Graduate School of Biomedical Sciences, Nagasaki University; 1-14 Bunkyo-machi, Nagasaki 852-8521, Japan: \\ and ${ }^{c}$ Hokkaido College of Pharmacy; Hokkaido 047-0264, Japan.
}

Received June 19, 2009; accepted July 10, 2009; published online July 13, 2009

Asymmetric intermolecular hydroacylation between salicylaldehyde (1) and 1,5-hexadiene (2) using a combination of $\left[\mathrm{RhCl}\left(\mathrm{C}_{8} \mathrm{H}_{14}\right)_{2}\right]_{2}(0.10 \mathrm{eq}),(S)$-BINAP $(0.10 \mathrm{eq})$, and $\mathrm{ZnBr}_{2}(0.20 \mathrm{eq})$ afforded an enantiomerically enriched hydroacylated product iso-3 of $84 \%$ ee, along with an achiral product normal-3.

Key words rhodium; intermolecular hydroacylation; chelation; enantioselective reaction

Rh-catalyzed intramolecular ${ }^{1-7)}$ and intermolecular hydroacylations $^{8-19)}$ have recently been the focus of synthetic organic and organometallic chemists. Although Rh-catalyzed asymmetric intramolecular hydroacylation (asymmetric cyclization) has been extensively studied by us, ${ }^{20-24)}$ and other groups ${ }^{25-28)} \mathrm{Rh}$-catalyzed asymmetric intermolecular hydroacylation has attracted only limited attention, ${ }^{29-31)}$ except for asymmetric hydroformylation. ${ }^{32,33)}$ This may be because $\mathrm{Rh}$-catalyzed intermolecular hydroacylation did not proceed under mild reaction conditions, but required vigorous reaction conditions. Recently, we have found that Rh-catalyzed intermolecular hydroacylations proceed under mild reaction conditions based on the "double chelation" of aldehyde and diene (Eq. 1). ${ }^{34-37)}$ Here we report enantioselective Rh-catalyzed intermolecular hydroacylation between salicylaldehyde (1) and 1,5-hexadiene (2).

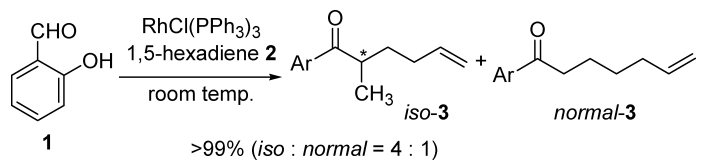

The hydroacylation between salicylaldehyde (1) and 1,5hexadiene (2, 6 eq) using $\mathrm{RhCl}\left(\mathrm{PPh}_{3}\right)_{3}(0.20$ eq) at room temperature afforded a mixture of iso-hydroacylated product 3 and normal-hydroacylated product 3 in the ratio of 4 to 1 in quantitative yield (Eq. 1). The iso-hydroacylated product 3 has a chiral carbon at the $\alpha$-position. Thus, we envisaged that the asymmetric induction from prochiral 1,5-hexadiene would be possible, if Rh-complex with chiral phosphine ligand were used instead of achiral $\mathrm{RhCl}\left(\mathrm{PPh}_{3}\right)_{3}$.

First, we examined the hydroacylation between salicylaldehyde (1) and 1,5-hexadiene (2) using $\mathrm{Rh}[(R)$-BINAP $] \mathrm{Cl}$ $(0.40 \mathrm{eq})$ at room temperature. Fortunately, the reaction afforded the mixture of iso-3 and normal-3 in the ratio of 3 to 1 , and the specific rotation $[\alpha]_{D}$ of the mixture showed +9.6 . This result means that the iso-product is not racemic but optically active, even though the chemical yield was merely $4 \%$ (entry 1 in Table 1). This result prompted us to further improve the chemical yield of the product and increase its specific rotation. We increased the amount of Rh-catalyst to 1.0 eq, but the yield of products was not improved. Several additives, such as bases, silver salts, and Lewis acids, were then examined, as shown in Table 1. We thought that the addition of base would deprotonate phenolic protons of salicyl- aldehyde and promote hydroacylation. In contrast, the addition of silver salt would change the property of Rh-complex to a cationic species to accelerate the reaction. Unfortunately, the addition of bases, such as $\mathrm{K}_{2} \mathrm{CO}_{3}, \mathrm{KOAc}$, and $\mathrm{NaOAc}$, did not improve the yield (entries 3-5), and the addition of silver salts, such as $\mathrm{AgClO}_{4}$ and $\mathrm{CF}_{3} \mathrm{CO}_{2} \mathrm{Ag}$, improved the yield of products but their specific rotations were zero, meaning that the products were racemic (entries 6-8). Finally, it was found that the addition of Lewis acid improved the yield of products (entries 9-12); in particular, the addition of $\mathrm{Zn}(\mathrm{OTf})_{2}(0.20 \mathrm{eq})$ improved the yield of product and its specific rotation showed $-26^{\circ}$ (entry 11 ). However, the addition of $\mathrm{Zn}(\mathrm{OTf})_{2}$ and elevated temperature $\left(50^{\circ} \mathrm{C}\right)$ induced the migration of olefin function to produce inseparable olefin mixtures of iso-3, along with normal-3 as a by-product. Therefore, the enantiomeric excess of iso-3 could not be directly determined by HPLC using a chiral column. Thus, the mixture of products was hydrogenated by $\mathrm{H}_{2} / 5 \% \mathrm{Pd}-\mathrm{C}$ to produce saturated hydroacylated products iso-4 and normal-4

Table 1. Effect of Additive on Asymmetric Intermolecular Hydroacylation

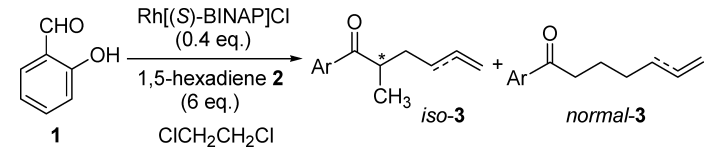

\begin{tabular}{|c|c|c|c|c|c|}
\hline Entry & $\begin{array}{l}\text { Additive } \\
\text { (eq) }\end{array}$ & $\begin{array}{l}\text { Temp. } \\
\left({ }^{\circ} \mathrm{C}\right)\end{array}$ & $\begin{array}{l}\text { Time } \\
\text { (h) }\end{array}$ & $\begin{array}{l}\text { 3: Yield \% } \\
\quad(i: n)\end{array}$ & {$[\alpha]_{\mathrm{D}}^{a)}$} \\
\hline 1 & - & $\mathrm{rt}^{b)}$ & 120 & $4(3: 1)$ & +9.6 \\
\hline $2^{c)}$ & - & $\mathrm{rt}$ & 120 & $5(3: 1)$ & d) \\
\hline 3 & $\mathrm{~K}_{2} \mathrm{CO}_{3}(0.4)^{e)}$ & $\mathrm{rt}$ & 120 & $2(2: 1)$ & -d) $^{(1)}$ \\
\hline 4 & $\left.\mathrm{~K}_{2} \mathrm{CO}_{3}(0.4)^{f}\right)$ & 40 & 120 & $13(2: 1)$ & -d) $^{\text {(n) }}$ \\
\hline 5 & $\operatorname{KOAc}(0.4)^{f}$ & 40 & 120 & $16(3: 1)$ & -d) \\
\hline 6 & $\mathrm{AgClO}_{4}(0.4)$ & 40 & 120 & $23(3: 1)$ & 0 \\
\hline 7 & $\begin{array}{l}\mathrm{AgClO}_{4}(0.4) \\
\mathrm{NaOAc}(0.4)^{f)}\end{array}$ & 50 & 14 & $90(2: 1)$ & 0 \\
\hline 8 & $\begin{array}{l}\mathrm{CF}_{3} \mathrm{CO}_{2} \mathrm{Ag}(0.4), \\
\mathrm{NaOAc}(0.4)^{f)}\end{array}$ & 50 & 72 & $88(4: 1)$ & 0 \\
\hline 9 & $\operatorname{Mg}(\mathrm{OTf})_{2}(0.2)^{f)}$ & 50 & 72 & $22(2: 1)$ & -1.8 \\
\hline 10 & $\operatorname{MgCl}_{2}(0.2)^{f}$ & 50 & 72 & Trace & — $^{d}$ \\
\hline 11 & $\mathrm{Zn}(\mathrm{OTf})_{2}(0.2)^{f)}$ & 50 & 48 & $85(3: 1)$ & $-26.8^{g)}$ \\
\hline 12 & $\mathrm{Cu}(\mathrm{OTf})_{2}(0.2)^{f)}$ & 50 & 72 & $17(1: 1)$ & -1.8 \\
\hline
\end{tabular}

a) Specific rotation of the mixture of products. b) Reaction at $50{ }^{\circ} \mathrm{C}$ afforded a mixture of products in $15 \%$ yield. c) 1.0 eq of Rh-complex was used. d) Not measured. e) $\mathrm{NaOAc}$ was also examined. f) $5 \% \mathrm{EtOH}$ in $\mathrm{ClCH}_{2} \mathrm{CH}_{2} \mathrm{Cl}$ was used as a solvent. $g$ ) Enantiomeric excess of $i s o-3$ was $68 \%$ ee. 
in quantitative yield, and the enantiomeric excess of iso-4 was determined by HPLC using a chiral column. The enantiomeric excess of iso-4 in entry 11 was determined to be $68 \%$ ee.

Next, we studied the effect of chiral bidentate phosphine ligand on the enantiomeric excess of product. The results are summarized in Table 2. We examined hydroacylation using $\mathrm{Rh}$ (ligand)Cl $(0.20 \mathrm{eq})$ and $\mathrm{Zn}(\mathrm{OTf})_{2}(0.10 \mathrm{eq})$ at $50^{\circ} \mathrm{C}$. In these conditions, where a reduced amount of $\mathrm{Rh}$-catalyst was used, the yield of products generally decreased, except for the $(R, R)$-Me-BPE ligand, and enantiomeric excesses fell. Even using $\mathrm{Rh}[(S)$-BINAP $] \mathrm{Cl}(0.20 \mathrm{eq})$, the enantiomeric excess of iso-3 decreased to $53 \%$ ee (entry 1 ). Thus, we have not found a phosphine ligand which showed better enantiomeric excess than the $(S)$-BINAP ligand.

We optimized the reaction conditions of Rh-catalyzed hydroacylation in the presence of zinc salts (Table 3). Hydroacylation by $\mathrm{Rh}[(S)$-BINAP $] \mathrm{Cl}(0.20 \mathrm{eq})$ in the presence of $\mathrm{Zn}(\mathrm{OTf})_{2}$ and $\mathrm{K}_{2} \mathrm{CO}_{3}$ did not efficiently proceed at room temperature (entry 1). The equivalence of $\mathrm{Zn}(\mathrm{OTf})_{2}$ was tested (entries 2-4), and when $0.10-0.20$ eq $\mathrm{Zn}(\mathrm{OTf})_{2}$ was added, the reaction afforded $i s o-3$ of $53-54 \%$ ee (entries 3, 4), but the decrease of $\mathrm{Zn}(\mathrm{OTf})_{2}$ to 0.05 eq was disadvantageous for the enantiomeric excess of the product. Furthermore, addition of a base was detrimental to the enantiomeric excess (entry 5). When $\mathrm{ZnBr}_{2}(0.10$ or $0.20 \mathrm{eq})$ was added as a zinc salt, the best enantiomeric excess $(78 \%$ ee) of iso-3 was attained (entries 6-9), although the ratio of iso/normal (2:1) was not good.

In the aforementioned reactions, the neutral $\mathrm{Rh}$-complex $\mathrm{Rh}[(R)$-BINAP $] \mathrm{Cl}$ was prepared in situ by mixing $\left[\mathrm{RhCl}\left(\mathrm{C}_{8} \mathrm{H}_{14}\right)_{2}\right]_{2}(0.10 \mathrm{eq}, 0.20 \mathrm{eq}$ as $\mathrm{Rh}-\mathrm{metal})$ with bidentate phosphine ligand $(S)$-BINAP $\left(0.2\right.$ eq) in $5 \% \mathrm{EtOH}_{\text {of }} \mathrm{ClCH}_{2}-$ $\mathrm{CH}_{2} \mathrm{Cl}$ solution, ${ }^{38)}$ and then the ratio of $\left[\mathrm{RhCl}\left(\mathrm{C}_{8} \mathrm{H}_{14}\right)_{2}\right]_{2}$ and BINAP ligand was checked. The results are summarized in Table 4. A reduced amount of $(S)$-BINAP ligand to $0.10 \mathrm{eq}$, that is to say, the ratio of Rh-metal/ligand is $2 / 1$, enhanced the enantiomeric excess of iso-(-)-3 to $84 \%$ ee, although the ratio of iso/normal decreased (entry 2). However, the use of further reduced $(S)$-BINAP ligand $(0.05 \mathrm{eq})$ was detrimental to the reaction and the enantiomeric excess (entry 3$)$. Enantiomeric $(R)$-BINAP ligand afforded the enantiomeric $(+)$ product (entry 4 ). To improve the enantiomeric excess, the reaction was performed at $40^{\circ} \mathrm{C}$, but a lower temperature was disadvantageous, and the enantiomeric excess of iso-3 decreased to $71 \%$ ee (entry 5 ). The best enantiomeric excess ( $84 \%$ ee) of iso-3 was attained in entries 2 and 4 of Table 4, although under these reaction conditions a mixture of isoand normal-3 in the ratio of 1 to 1 was obtained, and the migration of olefin in the products was observed.

The reaction mechanisms, such as the role of zinc salt, and the enantio-face selection are unclear. We considered that zinc salt as Lewis acid may coordinate the carbonyl function of aldehyde and promote the reaction. The best enantiomeric excess of iso-3 (84\% ee as a hydrogenated iso-4) was attained when the reaction was performed using the ratio of 2 to 1 of Rh-metal and BINAP ligand; thus, the real Rh-catalyst may be dimeric Rh-complexes, such as $\eta^{6}$-Ph-bi-Rhcomplexes and $\mu_{2}$-ligand-Rh-complexes.

In summary, we developed asymmetric intermolecular hydroacylation between salicylaldehyde $\mathbf{1}$ and 1,5-hexadiene 2
Table 2. Effect of Phosphine Ligand on Asymmetric Hydroacylation

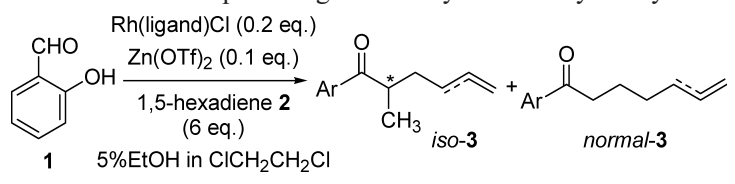

\begin{tabular}{clccc}
\hline \hline Entry & \multicolumn{1}{c}{ Ligand $^{a)}$} & $\begin{array}{c}\text { Time } \\
(\mathrm{h})\end{array}$ & $\begin{array}{c}\text { Yield \% } \\
(i: n)\end{array}$ & iso-3 \% ee \\
\hline 1 & $(S)$-BINAP & 72 & $68(2: 1)$ & 53 \\
2 & $(S)$-Tol-BINAP & 72 & $65(1: 1)$ & 53 \\
3 & $(R, R)$-Me-BPE & 48 & $85(1: 2)$ & 6 \\
4 & $(R, R)$-Me-DUPHOS & 72 & $18(1: 2)$ & 17 \\
5 & $(R, R)$-DIOP & 72 & $50(4: 1)$ & 0 \\
6 & $(S)$-(R)-PPFA & 72 & $45(2: 1)$ & 0 \\
\hline
\end{tabular}

a) Abbreviations: (S)-BINAP: $(S)$-2,2'-bis(diphenylphosphino)-1,1'-binaphthyl; $(S)$ Tol-BINAP: $(S)$-2,2'-bis(di-p-tolylphosphino)-1,1'-binaphthyl; $(R, R)$-Me-BPE: 1,2-bis$((2 R, 5 R)$-2,5-dimethylphospholano)ethane; $(R, R)$-Me-DUPHOS: 1,2 -bis $((2 R, 5 R)-2,5$ dimethylphospholano)benzene; $(R, R)$-DIOP: $(4 R, 5 R)-4,5$-bis(diphenylphosphinomethyl)-2,2-dimethyl-1,3-dioxolane; $\quad(S)$-(R)-PPFA: $\quad(R)$ - $N, N$-dimethyl-1-[(S)-2-(diphenylphosphino)ferrocenyl]ethylamine.

Table 3. Effect of Zinc Salts and Reaction Conditions on Intermolecular Hydroacylation

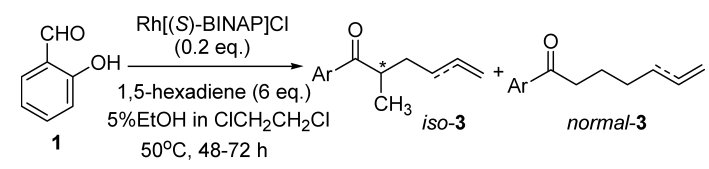

\begin{tabular}{clcc}
\hline \hline Entry & \multicolumn{1}{c}{ Zinc salt (eq) } & Yield \% $(i: n)$ & iso-3 \% ee \\
\hline 1 & $\mathrm{Zn}(\mathrm{OTf})_{2}(0.2), \mathrm{K}_{2} \mathrm{CO}_{3}(0.2)^{a)}$ & $5(2: 1)$ & - $^{b}$ \\
2 & $\mathrm{Zn}(\mathrm{OTf})_{2}(0.05)$ & $84(2: 1)$ & 44 \\
$3^{c)}$ & $\mathrm{Zn}(\mathrm{OTf})_{2}(0.1)$ & $68(2: 1)$ & 53 \\
4 & $\mathrm{Zn}(\mathrm{OTf})_{2}(0.2)$ & $78(2: 1)$ & 54 \\
5 & $\mathrm{Zn}(\mathrm{OTf})_{2}(0.1), \mathrm{K}_{3} \mathrm{PO}_{4}(0.1)$ & $82(2: 1)$ & 8 \\
6 & $\mathrm{ZnCl}_{2}(0.1)$ & $96(2: 1)$ & 62 \\
7 & $\mathrm{ZnBr}_{2}(0.1)$ & $81(1: 1)$ & 77 \\
8 & $\mathrm{ZnBr}_{2}(0.2)$ & $83(2: 1)$ & 78 \\
9 & $\mathrm{ZnI}_{2}(0.1)$ & $75(2: 1)$ & 60 \\
\hline
\end{tabular}

a) Reaction was carried out at room temperature. b) Not measured. c) Entry 3 is same as entry 1 in Table 2 .

Table 4. Effect of Ratio of $\mathrm{RhCl}\left[\left(\mathrm{C}_{8} \mathrm{H}_{14}\right)_{2}\right]_{2}$ and Phosphine Ligand BINAP

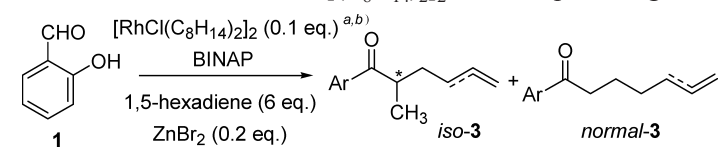

\begin{tabular}{clccc}
\hline \hline Entry & BINAP (eq) & Yield \% $(i: n)$ & iso-3 \% ee & $\left.[\alpha]_{\mathrm{D}}{ }^{c}\right)$ \\
\hline $1^{d)}$ & $(S)$-BINAP $(0.2)$ & $83(2: 1)$ & 78 & -30.8 \\
2 & $(S)$-BINAP $(0.1)$ & $86(1: 1)$ & 84 & -26.7 \\
3 & $(S)$-BINAP $(0.05)$ & $68(1: 2)$ & 61 & -15.8 \\
4 & $(R)$-BINAP $(0.1)$ & $81(1: 1)$ & 84 & +24.8 \\
$5^{e)}$ & $(S)$-BINAP $(0.1)$ & $89(1: 1)$ & 71 & -21.2 \\
\hline
\end{tabular}

a) 0.2 eq as Rh-metal. b) $5 \% \mathrm{EtOH}$ in $\mathrm{ClCH}_{2} \mathrm{CH}_{2} \mathrm{Cl}$ was used as a solvent, and the reaction was performed at $50{ }^{\circ} \mathrm{C}$. c) Specific rotation of mixture of iso- and normal3. d) Entry 1 is the same as entry 8 in Table 3. e) Reaction was performed at $40^{\circ} \mathrm{C}$.

using a combination of $\left[\mathrm{RhCl}\left(\mathrm{C}_{8} \mathrm{H}_{14}\right)_{2}\right]_{2},(S)$-BINAP, and $\mathrm{ZnBr}_{2}$. The reaction afforded an enantiomerically enriched hydroacylated iso-3 of $84 \%$ ee (as a hydrogenated iso-4), along with an achiral normal-3 in $86 \%$ yield. $\left.{ }^{39}\right)$

\section{Experimental}

Typical Procedure A solution of $\left[\mathrm{RhCl}\left(\mathrm{C}_{8} \mathrm{H}_{14}\right)_{2}\right]_{2}(72 \mathrm{mg}, 0.10 \mathrm{mmol}$, $0.20 \mathrm{mmol}$ as Rh-metal) and $(S)$-BINAP $(62.3 \mathrm{mg}, 0.10 \mathrm{mmol})$ in $5 \% \mathrm{EtOH}$ 
of $\mathrm{ClCH}_{2} \mathrm{CH}_{2} \mathrm{Cl}(4 \mathrm{ml})$ was stirred at room temperature for $1 \mathrm{~h}$ under $\mathrm{Ar}$ atmosphere. Then, salicylaldehyde (1, $122 \mathrm{mg}, 1.0 \mathrm{mmol}), 1,5$-hexadiene (2, $493 \mathrm{mg}, 6.0 \mathrm{mmol}$ ), and $\mathrm{ZnBr}_{2}(45 \mathrm{mg}, 0.20 \mathrm{mmol})$ were added, and the solution was stirred at $50^{\circ} \mathrm{C}$ under Ar atmosphere. After being stirred for $48 \mathrm{~h}$, $\mathrm{Et}_{2} \mathrm{O}$ was added, and the resulting precipitate was filtered off. After removal of the solvent, the residue was purified by column chromatography on silica gel $(10 \%$ EtOAc in hexane) to give a $1: 1$ mixture of iso-3 and normal-3 $(176 \mathrm{mg}, 86 \%)$ as a colorless oil. $[\alpha]_{\mathrm{D}}-26.7\left(c=1.0, \mathrm{CHCl}_{3}\right)$.

1-(2-Hydroxyphenyl)-2-methylhexan-1-one (iso-4) and 1-(2-Hydroxyphenyl)heptan-1-one (normal-4) A mixture of iso-3 and normal-3 $(50 \mathrm{mg}, 0.245 \mathrm{mmol})$ and $5 \% \mathrm{Pd}-\mathrm{C}(50 \mathrm{mg})$ in $\mathrm{MeOH}(5 \mathrm{ml})$ was rigorously stirred under $\mathrm{H}_{2}$ atmosphere at room temperature for $4 \mathrm{~h}$. Then, the Pd-catalyst was filtered off, and the filtrate was evaporated in vacuo. The residue was purified by column chromatography on silica gel (10\% EtOAc in hexane) to leave iso-4 and normal-5 (50 mg, quantitative) as a colorless oil. Both isomers could be separated by preparative TLC. iso-4: a colorless oil; IR (neat) $\mathrm{cm}^{-1}: 3045,2959,2932,1638 ;{ }^{1} \mathrm{H}-\mathrm{NMR}\left(400 \mathrm{MHz}, \mathrm{CDCl}_{3}\right) \delta: 12.6(1 \mathrm{H}, \mathrm{s})$, $7.76(1 \mathrm{H}$, brd, $J=8 \mathrm{~Hz}), 7.43(1 \mathrm{H}$, br t, $J=8 \mathrm{~Hz}), 6.97(1 \mathrm{H}$, brd, $J=8 \mathrm{~Hz})$, $6.87(1 \mathrm{H}$, br t, $J=8 \mathrm{~Hz}), 3.48(1 \mathrm{H}$, sestet, $J=6.5 \mathrm{~Hz}), 1.80(1 \mathrm{H}, \mathrm{m}), 1.39(1 \mathrm{H}$, m), $1.28(2 \mathrm{H}, \mathrm{m}), 1.19-1.20(5 \mathrm{H}, \mathrm{m}), 0.86(3 \mathrm{H}, \mathrm{t}, J=6.5 \mathrm{~Hz}) \mathrm{ppm}$; FABMS $m / z: 207\left[(\mathrm{M}+1)^{+}\right]$. normal-4: a colorless oil; IR (neat) $\mathrm{cm}^{-1}: 3039$, 2955, 2929, 1639; ${ }^{1} \mathrm{H}-\mathrm{NMR}\left(400 \mathrm{MHz}, \mathrm{CDCl}_{3}\right) \delta: 12.4(1 \mathrm{H}, \mathrm{s}), 7.74(1 \mathrm{H}$, brd, $J=8 \mathrm{~Hz}), 7.43(1 \mathrm{H}$, br t, $J=8 \mathrm{~Hz}), 6.95(1 \mathrm{H}$, br d, $J=8 \mathrm{~Hz}), 6.87(1 \mathrm{H}$, br t, $J=8 \mathrm{~Hz}), 2.96(2 \mathrm{H}, \mathrm{t}, J=7.4 \mathrm{~Hz}), 1.72(2 \mathrm{H}$, quintet, $J=7.4 \mathrm{~Hz}), 1.19$ $1.39(6 \mathrm{H}, \mathrm{m}), 0.88(3 \mathrm{H}, \mathrm{t}, J=6.5 \mathrm{~Hz})$ ppm; FAB-MS $m / z: 207\left[(\mathrm{M}+1)^{+}\right]$.

Determination of the Enantiomeric Excess of iso-3 The enantiomeric excess of $i s o-\mathbf{3}$ was determined by HPLC, after conversion of iso-3 into iso4 by hydrogenation. HPLC conditions: column: CHIRALCEL OB-H, $0.46 \mathrm{~cm} \phi \times 25 \mathrm{~cm}$; detection: UV $254 \mathrm{~nm}$; eluent: $0.1 \%$ iso-PrOH in hexane; flow rate: $0.5 \mathrm{ml} / \mathrm{min}$; retention time $\left(t_{\mathrm{R}}\right)$ : (-)-iso-4, $9.8 \mathrm{~min},(+)$-iso-4, 11.8 min, normal-4, $15 \mathrm{~min}$.

Acknowledgements This work was supported in part by a Grant-in-Aid for Young Scientists (B) from the Japan Society for the Promotion of Science.

\section{References and Notes}

1) Sakai K., Ide J., Oda O., Nakamura N., Tetrahedron Lett., 13, 1287 1290 (1972).

2) Fairlie D. P., Bosnich B., Organometallics, 7, 936-945 (1988).

3) Aloise A. D., Layton M. E., Shair M. D., J. Am. Chem. Soc., 122, 12610-12611 (2000).

4) Bendorf H. D., Colella C. M., Dixon E. C., Marchetti M., Matukonis A. N., Musselman J. D., Tiley T. A., Tetrahedron Lett., 43, 70317034 (2002).

5) Sato Y., Oonishi Y., Mori M., Angew. Chem., Int. Ed., 41, 1218-1221 (2002).

6) Takeishi K., Sugishima K., Sasaki K., Tanaka K., Chem. Eur. J., 10, $5681-5688$ (2004).

7) Hyatt I. F. D., Anderson H. K., Morehead A. T. Jr., Sargent A. L., Organometallics, 27, 135-147 (2008).

8) Kokubo K., Matsumasa K., Nishinaka Y., Miura M., Nomura M., Bull. Chem. Soc. Jpn., 72, 303-311 (1999).

9) Miura M., Nomura M., J. Synth. Org. Chem. Jpn., 58, 578-586 (2000).

10) Jun C.-H., Hong J.-B., Lee D.-Y., Synlett, 1999, 1-12 (1999).

11) Jun C.-H., Lee D.-Y., Lee H., Hong J.-B., Angew. Chem. Int. Ed., 39, $3070-3072$ (2000).

12) Jun C.-H., Moon C. W., Lee D.-Y., Chem. Eur. J., 8, 2422-2428 (2002).
13) Jun C.-H., Moon C. W., Lee H., Lee D.-Y., J. Mol. Cat. A: Chem., 189, $145-156$ (2002).

14) Willis M. C., McNally S. J., Beswick P. J., Angew. Chem. Int. Ed., 43, $340-343$ (2004).

15) Willis M. C., Randell-Sly H. E., Woodward R. L., McNally S. J., Currie G. S., J. Org. Chem., 71, 5291-5297 (2006).

16) Hong Y.-T., Barchuk A., Krische M. J., Angew. Chem. Int. Ed., 45, $6885-6888$ (2006).

17) Jun C.-H., Jo E.-A., Park J.-W., Eur. J. Org. Chem., 2007, 1869-1881 (2007).

18) Tanaka K., Shibata Y., Suda T., Hagiwara Y., Hirano M., Org. Lett., 9, 1215-1218 (2007)

19) Shimizu M., Tsurugi H., Satoh T., Miura M., Chem. Asian J., 3, 881886 (2008).

20) Our asymmetric Rh-catalyzed intramolecular hydroacylations. See refs. 20-24: Sakai K., Ishiguro Y., Funakoshi K., Ueno K., Suemune H., Tetrahedron Lett., 25, 961-964 (1984).

21) Taura Y., Tanaka M., Wu W.-M., Funakoshi K., Sakai K., Tetrahedron, 47, 4879-4888 (1991).

22) Tanaka M., Imai M., Fujio M., Sakamoto E., Takahashi M., Eto-Kato Y., Wu W.-M., Funakoshi K., Sakai K., Suemune H., J. Org. Chem., 65, 5806-5816 (2000)

23) Tanaka M., Takahashi M., Sakamoto E., Imai M., Matsui A., Fujio M., Funakoshi K., Sakai K., Suemune H., Tetrahedron, 57, 1197-1204 (2001).

24) Tanaka M., Sakai K., Suemune H., Cur. Org. Chem., 7, 353-367 (2003).

25) James B. R., Young C. G., J. Chem. Soc., Chem. Commun., 1983, 1215-1216 (1983)

26) Bosnich B., Acc. Chem. Res., 31, 667-674 (1998).

27) Tanaka K., Fu G. C., J. Am. Chem. Soc., 125, 8078-8079 (2003).

28) Tanaka K., J. Synth. Org. Chem. Jpn., 63, 351-358 (2005).

29) While we were studying an asymmetric intermolecular hydroacylation between salicylaldehyde and 1,5-hexadiene, Bolm et al., reported an unprecedented Rh-catalyzed asymmetric intermolecular hydroacylation of norbornadiene and norbornene. Also, Willis et al., reported the Rh-catalyzed asymmetric intermolecular hydroacylation of allenes. See refs. 30 and 31 .

30) Stemmler R. T., Bolm C., Adv. Synth. Catal., 349, 1185-1198 (2007).

31) Osborne J. D., Randell-Sly H. E., Currie G. S., Cowley A. R., Willis M. C., J. Am. Chem. Soc., 130, $17232-17233$ (2008)

32) Nozaki K., Sakai N., Nanno T., Higashijima T., Mano S., Horiuchi T., Takaya H., J. Am. Chem. Soc., 119, 4413-4423 (1997).

33) Breit B., Seiche W., Synthesis, 2001, 1-36 (2001).

34) Tanaka M., Imai M., Yamamoto Y., Tanaka K., Shimowatari M., Nagumo S., Kawahara N., Suemune H., Org. Lett., 5, 1365-1367 (2003).

35) Imai M., Tanaka M., Tanaka K., Yamamoto Y., Imai-Ogata N., Shimowatari M., Nagumo S., Kawahara N., Suemune H., J. Org. Chem., 69, $1144-1150$ (2004).

36) Tanaka K., Tanaka M., Suemune H., Tetrahedron Lett., 46, 60536056 (2005).

37) Imai M., Tanaka M., Nagumo S., Kawahara N., Suemune H., J. Org. Chem., 72, 2543-2546 (2007).

38) The Rh-catalyzed intermolecular reaction in $5 \% \mathrm{EtOH}$ of $\mathrm{ClCH}_{2} \mathrm{CH}_{2} \mathrm{Cl}$ solution gave good results. See refs. $34-37$.

39) The Rh-catalyzed asymmetric intermolecular hydroacylation of norbornene derivatives with salicylaldehyde was attempted under the same reaction conditions, but the hydroacylation did not proceed in the presence of $\mathrm{Zn}$ salts. 